\title{
KEBIJAKAN FISKAL ZAMAN RASULULLAH DAN KHULAFARASYIDIN
}

\author{
Mike Oktaviana ${ }^{1}$, Samsul Bahry Harahap ${ }^{2}$ \\ ${ }^{1,2}$ Institut Agama Islam Negeri (IAIN) Kerinci \\ samsulbahryharahap@gmail.com
}

\begin{abstract}
Abstrak
Dalam Islam, kebijakan fiskal merupakan suatu kewajiban negara dan menjadi hak rakyat, sehingga kebijakan fiskal bukanlah semata-mata sebagai suatu kebutuhan untuk perbaikan ekonomi maupun untuk peningkatan kesejahteraan rakyat saja, akan tetapi lebih pada penciptaan mekanisme distribusi ekonomi yang adil. Kebijakan Fiskal dalam Islam sudah ada sejak Zaman Rasulullah saw. Mekanisme distribusi sumber pendapatan negara Islam adalah fai', ghanimah, kharaj, jizyah, ushur dan khumus. Mengenai zakat, itu adalah bantuan sosial swasembada yang bermoral kewajiban bagi orang kaya untuk membantu mereka yang miskin dan terlantar. Sember pendapatan Negara sejak Zaman Rasulullah saw hingga masa pemerintahan khulafarasyidin adalah sama hanya saja konsep dalam pendistribusiannya berbeda.
\end{abstract}

Kata Kunci : Kebijakan Fiskal, Rasulullah SAW, Khulafarasidin

\section{PENDAHULUAN}

Memasuki abad XXI ini, umat Islam dihadapkan pada harapan-harapan historis, sekaligus tantangan yang cukup besar khususnya berkenaan dengan sistem ekonomi. Sistem ekonomi global yang digaungkan saat ini membuat umat Islam di belahan manapun mengalami masa yang menentukan. Bukan saja karena kondisi ekonomi dan politiknya yang masih dipengaruhi oleh negara-negara maju, tetapi suatu nasib apakah umat Islam memiliki kekuatan baru untuk mempengaruhi sistem ekonomi dunia. Atau sebaliknya, umat Islam yang selama ini sebagian besar berada di bawah garis kemakmuran, justru semakin terpuruk sebagai konsumen produksi negara-negara maju.

Sistem kapitalisme Barat yang dominan. Seiring dengan berjalannya waktu, sistem kapitalisme barat telah menunjukkan kelemahan serta bayangan kebobrokannya. Sistem ekonomi kapitalis mempunyai prinsip dasar mendapatkan keuntungan semaksimal mungkin dengan sumber daya yang 
terbatas. Usaha kapitalis ini didukung oleh nilai-nilai kebebasan untuk memenuhi kebutuhan. Manusia mempunyai kebebasan yang luas untuk memiliki harta.

Prinsip-prinsiptersebut mengakibatkan ketimpangan sosial yang secara tidak langsung telah membuat polarisasi yang cukup tajam antara kaya dan miskin. Selain itu kapitalisme juga menjerumuskan manusia pada kehidupan yang materialistis. Keadaan ini mempersempit ruang bagi manusia untuk berinteraksi dengan masyarakat sekitar. Akhirnya hal ini mengakibatkan manusia kehilangan unsur-unsur kemanusiaannya (dehumanisasi) dan terasing oleh dirinya sendiri (alienasi). (Nabhani, 1996:1)

Prinsip-prinsip ekonomi Islam yang mengakui kebebasan manusia atas nilai-nilai tauhid, hak memiliki harta atas dasar kemaslahatan, melarang penumpukan harta, serta distribusi kekayaan justru yang sesuai dengan sifat dasar dan kebutuhan manusia. (Sudarsono, 2004:124). Terkait dengan pemenuhan kebutuhan manusia, maka dalam Islam telah diatur mekanismenya dalam suatu negara. Peran Negara Islam sangat signifikan dalam menjamin kesejahteraan dan kebutuhan rakyatnya. Dalam rangka menjamin kesejahteraan rakyat, negara akan melakukan berbagai kebijakan. Kebijakan tersebut dinamakan kebijakan fiskal.

Menurut Wolfson sebagaimana dikutip Suparmoko, kebijakan fiskal (fiskal policy) merupakan tindakan-tindakan pemerintah untuk meningkatkan kesejahteraan umum melalui kebijakan penerimaan dan pengeluaran pemerintah, mobilisasi sumberdaya, dan penentuan harga barang dan jasa dari perusahaan. (Suparmoko, 1997:257). Sedangkan Samuelson dan Nordhaus menyatakan bahwa kebijakan fiskal adalah proses pembentukan perpajakan dan pengeluaran masyarakat dalam upaya menekan fluktuasi siklus bisnis, dan ikut berperan dalam menjaga pertumbuhan ekonomi, penggunaan tenaga kerja yang tinggi, bebas dari laju inflasi yang tinggi dan berubah-ubah. (Samuelson, dkk, 1997:346)

Dari dua definisi di atas dapat ditarik kesimpulan, bahwa kebijakan fiskal merupakan kebijakan pemerintah terhadap penerimaan dan pengeluaran negara untuk mencapai tujuan-tujuannya. Penarikan kesimpulan ini bertujuan 
agar definisi kebijakan fiskal mengandung makna umum, artinya ia merupakan suatu gambaran yang bisa terjadi dalam berbagai sistem ekonomi.

Selanjutnya, karena instrumen yang digunakan dalam kebijakan fiskal adalah penerimaan dan pengeluaran negara, maka kebijakan fiskal dalam konteks Sistem Ekonomi Kapitalis sangat erat kaitannya dengan target keuangan negara yang ingin dicapai. Dengan kata lain, target Anggaran Pendapatan dan Belanja Negara (APBN) yang ingin dicapai oleh pemerintah.

Merujuk hal di atas, dalam tulisan ini akan dipaparkan tentang kebijakan fiskal sebelum Islam dan dalam negara Islam awal (Pada Masa Rasulullah dan Khulafa Rasyidin), peran negara dalam mendapatkan sumber-sumber pendapatan, dan kebijakan fiskal sebagai fungsi alokasi, distribusi, dan stabilisasi perekonomian.

\section{KAJIAN TEORI}

Fiskal adalah sesuatu berkenaan dengan pajak dan pendapatan negara. Kebijakan Fiskal adalah suatu kebijakan ekonomi dalam rangka mengarahkan kondisi perekonomian untuk menjadi lebih baik dengan jalan mengubah penerimaan dan pengeluaran pemerintah. (Danupranata, 2006:34) Kebijakan ini mirip dengan kebijakan moneter untuk mengatur jumlah uang beredar, namun kebijakan fiskal lebih menekankan pada pengaturan pendapatan dan belanja pemerintah. Kebijakan fiskal juga dapat diartikan sebagai kebijakan yang dibuat pemerintah untuk mengarahkan ekonomi suatu negara melalui pengeluaran dan pendapatan (berupa pajak) pemerintah. Kebijakan ini dilakukan oleh pemerintah dalam rangka mendapatkan dana-dana dan kebijaksanaan yang ditempuh oleh pemerintah untuk membelanjakan dananya tersebut dalam rangka melaksanakan pembangunan.

Instrumen kebijakan fiskal adalah penerimaan dan pengeluaran pemerintah yang berhubungan erat dengan pajak. Dari sisi pajak jelas jika mengubah tarif pajak yang berlaku akan berpengaruh pada ekonomi. (Danupranata, 2006:34) Jika pajak diturunkan maka kemampuan daya beli masyarakat akan meningkat dan industri akan dapat meningkatkan jumlah output. Dan sebaliknya kenaikan pajak 
akan menurunkan daya beli masyarakat serta menurunkan output industri secara umum. Adapun instrumen-instrumen nya antara lain :

1. Anggaran Defisit (Defisit Budget)/Kebijakan Fiskal Ekspansif

2. Anggaran Surplus (Surplus Budget) / Kebijakan Fiskal Kontraktif

3. Anggaran Berimbang (Balanced Budget)

Adapun bentuk kebijakan fiskal adalah kebijakan yang menyangkut pembelian (pengeluaran) pemerintah atas barang dan jasa, kebijakan yang menyangkut perpajakan dan kebijakan yang menyangkut pembayaran transfer.

Kebijakan fiskal dalam pemerintahan Islam, telah dikenal sejak zaman Rasulullah SAW.(Hasan 2001:15)

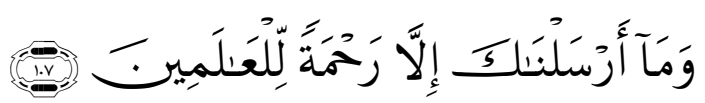

Artinya: Dan tiadalah kami mengutus kamu, melainkan untuk (menjadi) rahmat bagi semesta alam.(Q.S. Al-Anbiya: 107). (DEPAG RI, 2008: 331)

Pada masa itu Baitul Mal sebagai lembaga pengelolaan keuangan Negara. Kebijakan fiskal di Baitul Mal memberikan dampak positif terhadap tingkat investasi, penawaran agregat, dan secara tidak langsung memberikan dampak pada tingkat inflasi dan pertumbuhan ekonomi.

Pada dasarnya sistem ekonomi islam dibagi ke dalam tiga sektor yang utama, yaitu sektor publik, sektor swasta, dan juga sektor keadilan sosial. Sektor publik merupakan sektor perekonomian yang melibatkan peran negara, dan yang dimaksud dengan sektor publik ini juga dapat dianggap sebagai sektor fiskal. Fungsi daripada sektor kebijakan fiskal menurut Islam adalah :

1. Pemeliharaan terhadap hukum., keadilan dan juga pertahanan

2. Perumusan dan pelaksanaan terhadap kebijakan ekonomi

3. Manajemen kekayaan pemerintah yang ada di dalam BUMN

4. Intervensi ekonomi oleh pemerintah jika diperlukan

Fungsi ini pada dasarnya berlaku sama di dunia ini, meskipun dalam berbagai praktik dan implementasinya seringkali berbeda dan disesuaikan dengan Nazharat, Vol. 26 No. 01, Juni 2020 
kebijakan yang berlaku di dalam sebuah pemerintahan yang ada di dalam negara tersebut. Karena Islam merupakan agama yang bersifat rahmat bagi semesta alam, maka fungsi ini tidak hanya berlaku bagi negara Islam saja, akan tetapi juga berlaku bagi negara-negara yang bukan negara Islam atau negara yang penduduknya mayoritas Islam akan tetapi bukan berbentuk sebagai negara Islam.Dalam pandangan ekonomi Islam pendapatan dan anggaran merupakan alat yang efektif dalam rangka untuk mencapai tujuan ekonomi.

Adapun tujuan dari kebijakan fiskal dalam Islam adalah untuk menciptakan masyarakat yang didasarkan pada keseimbangan distribusi kekayaan dengan menempatkan nilai-nilai material dan spiritual secara seimbang. Kebijakan fiskal dalam ekonomi islam digunakan untuk kepentingan yang sama dengan kebijakan fiskal dalam ekonomi konvensional, yaitu sama-sama menganalisis dan membuat kebijakan ekonomi.(Arifin, 2009: 36)

Selain itu kebijakan fiskal dalam ekonomi islam pun terdapat suatu tujuan tertentu. Jikalau kebijakan fiskal dalam ekonomi kapitalis mempunyai tujuan untuk pertumbuhan, stabilitas, dan sebagainya tetap sah dan diterima dalam ekonomi islam, tujuan-tujuan tersebut akan menjadi pengantar untuk tujuan selanjutnya dalam kebijakan islam, yaitu menanggulangi kaum muslim dan dakwah menyebarluaskan keseluruh penjuru dunia. Tujuan ini harus dipertimbangkan menjadi kebijakan publik dari kebijakan fiskal, sebab dengan adanya kebijakan fiskal ini diharapkan dapat membantu dalam pencapaian tujuan tersebut.

Menurut Metwalley, setidaknya ada tiga tujuan yang hendak dicapai oleh kebijakan fiskal dalam ekonomi islam, yaitu:

a. Islam menghendaki tingkat kesetaraan ekonomi yang demokratis melalui prinsip bahwa "kekayaan seharusnya tidak beredar diantara orang-orang kaya saja". Prinsip ini menegaskan bahwa setiap orang seharusnya memiliki akses yang sama dalam memperoleh kekayaan.

b. Islam melarang pembayaran bunga (riba). Hal ini berarti islam tidak dapat memanipulasi tngkat suku bunga untuk mencapai keseimbangan dalam pasar uang. 
c. Islam mempunyai komitmen untuk membantu ekonomi masyarakat yang kurang berkembang dan untuk menyebarkan pesan dan ajaran islam seluas mungkin.

\section{METODE PENELITIAN}

Dalam penelitian ini digunakan jenis penelitian pustaka (library research), yaitu penelitian yang menjadikan bahan kepustakaan ini dijadikan sebgai sumber (data) utama, baik data primer maupun sekunder dengan pendekatan kualitatif.

Sifat dari penelitian ini adalah deskriptif dan analitik, (Moleong, 2000:6) Penelitian ini berusaha memaparkan tentang kebijakan sistem fiskal secara umum sebelum akhirnya akan mendeskripsikan kerangka kebijakan sistem fiskal menurut ekonomi Islam, kemudian dilakukan analisis interpretasi tentang bagaimana kebijakan pemerintah dalam menentukan sistem fiskal suatu Negera dan melihat bagaimana sistem fiskal dalam negera Islam. Pendekatan yang digunakan dalam memperoleh data adalah menggunakan pendekatan normatif, yaitu suatu usaha untuk menjelaskan tentang kebijakan sistem fiskal melihat dari keputusan dan kebijakan pemerintah yang berkaitan dengan hal yang diteliti dipandang dari sisi hukum Ekonomi Islam. Artinya, penelitian ini juga dapat dilihat baik dari kaidah ushuliyah maupun fiqhiyyah. Hal ini penting, karena masalah kebijakan sistem fiskal merupakan salah satu persoalan kontemporer dari sekian banyak persoalan atau masalah-masalah baru.

\section{HASIL DAN PEMBAHASAN}

\section{Kebijakan Fiskal Sebelum Islam}

Pada masa Arab pra-Islam atau yang sering disebut masa jahiliyah sudah biasa melakukan transaksi berbau riba. Ath-Thabari menyatakan: "Pada masa jahiliyah, praktik riba terletak pada penggandaan dan kelebihan jumlah umur satu tahun. Misalnya, seorang berhutang. Ketika sudah jatuh tempo, datanglah pemberi hutang untuk menagihnya seraya berkata, 'Engkau akan membayar hutangmu 
ataukah akan memberikan tambahan (bunga) nya saja kepadaku, Jika ia memiliki sesuatu yang dapat ia bayarkan maka ia pun membayarnya. Jika tidak, maka ia akan menyempurnakannya hingga satu tahun ke depan. Jika hutangnya berupa ibnatu makhadh (anak unta yang berumur satu tahun), maka pembayarannya menjadi ibnatu labun (anak unta yang berumur dua tahun) pada tahun kedua. Kemudian la akan menjadikannya hiqqah (anak unta yang berumur tiga tahun), kemudian menjadikannya jadzah (unta dewasa). Selanjutnya kelipatan empat ke atas." Juga dalam hal hutang emas ataupun uang, berlaku riba.

Sebagai pelaku ekspor impor, jazirah Arab memiliki pusat kota tempat bertransaksi yaitu kota Makkah. Kota Makkah merupakan kota suci yang setiap tahunnya dikunjungi, terutama karena disitulah terdapat bangunan suci Ka'bah. Selain itu di Ukaz terdapat pasar sebagai tempat bertransaksi dari berbagai belahan dunia dan tempat berlangsungnya perlombaan kebudayaan (puisi Arab). (Hasan, 2003:11) Oleh karena itu kota tersebut menjadi pusat peradaban balk politik, ekonomi, dan budaya yang penting.

Makkah merupakan jalur persilangan ekonomi internasional, yaitu menghubungkan Makkah ke Abysinia seterusnya menuju ke Afrika Tengah. Dari Makkah ke Damaskus seterusnya ke daratan eropa. Dari Makkah ke al-Machin (Persia) ke Kabul, Kashmir, Singking (Sinjian) sampai ke Zaitun dan Canton, selanjutnya menembus daerah Melayu. Selain itu juga dari Makkah ke aden melalui laut menuju ke India, Nusantara, hingga Canton (al-Haddad). Hal ini menyebabkan masyarakat Makkah memiliki peran strategis untuk berpartisipasi dalam dunia perekonomian tersebut. Mereka digolongkan menjadi tiga, yaitu para konglomerat yang memiliki modal, kedua, para pedagang yang mengolah modal dan' para konglomerat, dan ketiga, para perampok dan rakyat biasa yang bemberikan jaimian keamanan kepada para khafilah pedagang dari peranatuan, mereka mendapatkan laba keuntungan sebesar sepuluh persen. (Lapidus, 1999:68)

Para pedagang tersebut menjual komoditas itu kepada para konglomerat, pejabat, tentara, dan keluarga penguasa, karena komoditas tersebut mahal, terutama barang-barang impor yang harus dikenai pajak yang sangat tinggi. Alat pembayaran yang mereka gunakan adalah koin yang terbuat dari perak, emas atau 
logam mula lain yang dittru dari mata uang Persia dan Romawi. Sampai sekarang koin tersebut masih tersimpan disejumlah museum di Timur Tengah.

Dari berbagai sumber sejarah diketahui bahwa mata uang pada masa jahiliyah dan pada masa permulaan Islam, terdiri, dari dua macam: dinar dan dirham. Mata uang dirham terbuat dari perak, terdiri dari tiga jenis: Bughliyah, Jaraqiyah, dan Thabariyah. Ukurannya beragam. Bughliyah beratnya 4,66 gram, Jaraqiyah beratnya 3,40 gram, dan Thabariyah beratnya 2,83 gram. Sedangkan mata uang dinar terbuat dari emas. Pada masa jahiliyah dan pada permulaan Islam, Syam dan Hijaz menggunakan mata uang Dinar yang seluruhnya adalah mata uang Romawi. Mata uang ini dibuat di negeri Romawi, berukiran gambar raja, bertuliskan huruf Romawi. Satu dinar pada masa itu setara dengan 10 dirham. (Hasyimi, 1975:27)

Dari keterangan di atas dapat disimpulkan bahwa pada masa sebelum Islam tidak ada ketentuan yang tetap tentang kebijakan fiskal, hanya saja letak kota mekkah yang strategis inilah yang menjadi pemasukan yakni dari pajak-pajak yang dibayar pedagang yang melewati jalur kota mekkah, lagi pula pada waktu itu masyarakat hidup berkabilah-kabilah atau berkelompok-kelompok sedangkan untuk menentukan siapa yang berkuasa adalah siapa yang paling kuat. Jadi tidak ada ketetapan yang bisa dijadikan acuan karena penguasanya bisa berganti setiap saat.

\section{Kebijakan Fiskal Zaman Rasulullah saw}

Situasi kehidupan Islam pada Masa awal tidaklah jauh berbeda dengan gambaran kehidupan yang ada pada masa setelahnya, hanya saja warna kehidupan masih lebih sederhana dan belum kompleks seperti kehidupan masyarakat Islam setelahnya. Masalahnya, mungkin terletak pada jumlah masyarakat Islam yang masih terkonsentrasi di Mekkah dan Madinah dan sebagian daerah jazirah Arab lainnya, dan belum terlalu luas dan menyebarnya daerah kekuasaan Islam. Sebelum hijrah, belum terlalu banyak aktifitas Rasulullah SAW, sahabat dan muslim lainnya yang menyangkut kehidupan secara makro dan menyangkut banyak orang, tetapi aktifitas itu baru terbatas pada konsentrasi penyebaran 
"harumnya" Islam. Kalaupun ada aktifitas selain dakwah Islam, aktifitas tersebut masih untuk kepentingan pribadi, termasuk juga aktifitas ekonomi. Sistem perekonomian yang terbentuk dari agregasi variabel-variabel ekonomi merupakan satu sistem yang simultan yang memadukan rangkaian sistem ekonomi. Sistem fiskal sebagai salah satu bagian dari tubuh perekonomian memiliki peran yang penting dalam perekonomian suatu Negara terutama berkaitan dengan kekuasaan Negara dalam turut serta mengatur perekonomian. (Danupranata, 2016:35)

Kebijakan fiskal atau yang sering disebut sebagai "politik fiskal" (fiskal policy). Bisa diartikan sebagai tindakan yang diambil oleh pemerintah dalam bidang anggaran belanja Negara dengan maksud untuk mempengaruhi jalannya perekonomian. Tujuan kebijakan fiskal dalam ekonomi Islam berbeda dari ekonomi konvensional, namun ada kesamaan yaitu dari segi sama-sama menganalisis dan membuat kebijakan ekonomi.

Pentingnya kebijakan ekonomi, khususnya kebijakan fiskal yang dijalankan oleh Rasulullah untuk menstabilkan pemerintahan Islam menjadi lebih dapat dimengerti jika dipahami besarnya kenaikan populasi kaum muslimin.(Karim, 2009:90) Langkah-langkah yang diambil Rasulullah, atas nama kaum muhajirin dan seluruh kaum muslimin di Madinah dan Hijaz, secara bertahap kesejahteraan muslimin mengalami perkembangan.

M.A Sabzwari dalam Journal of Islamic Banking and Finance menyebutkan bahwa Rasulullah SAW baru mulai "melirik" permasalahan ekonomi dan keuangan negara, setelah beliau menyelesaikan masalah politik dan urusan konstitusional di Madinah pada masa awal hijrah.

Dari sisi penerimaan APBN terdiri dari atas Kharaj (sejenis pajak tanah), zakat, dan penerimaan-penerimaan lainya. Disisi pengeluaran, terdiri atas pengeluaran untuk kepentingan dakwah, pendidikan dan kebudayaan, iptek, hankam, kesejahteraan sosial dan belanja pegawai.

Sumber-sumber pendapatan Negara:

\section{a. Ghanimah}


Pada tahun kedua Hijriyah, dalam surat Al Anfal: 41. Allah SWT. Menentukan tata cara pembagian harta ghanimah dengan formulasi sebagai berikut :

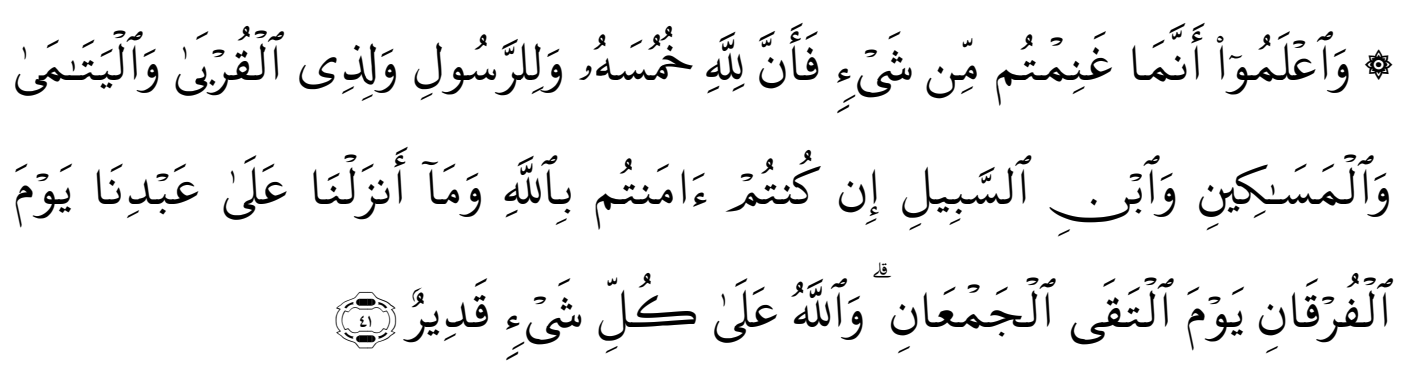

Artinya: Ketahuilah, Sesungguhnya apa saja yang dapat kamu peroleh sebagai rampasan perang, Maka Sesungguhnya seperlima untuk Allah, rasul, kerabat rasul, anak-anak yatim, orang-orang miskin dan ibnussabil, jika kamu beriman kepada Allah dan kepada apa yang kami turunkan kepada hamba kami (Muhammad) di hari Furqaan, yaitu di hari bertemunya dua pasukan. dan Allah Maha Kuasa atas segala sesuatu.

- Seperlima bagian untuk Allah dan Rasul-Nya. Dialokasikan bagi kesejahteraan umum dan untuk para kerabat, anak-anak yatim, orang-orang miskin dan para musafir.

- Empat perlima bagian lainnya dibagikan kepada para angggota pasukan yang terlibat dalam peperangan.

b. Zakat

Pada tahun kedua Hijriyah, Allah. SWT mewajibkan kaum muslimin menunaikan zakat fitrah pada setiap bulan Ramadhan. Dan Kewajiban zakat mal diperintahkan pada tahun ke-9 H. menurut Bukhari, Rasulullah SAW bersabda kepada Muadz, ketika ia mengirimnya ke Yaman sebagai pengumpul dan pemberi zakat, "Katakan kepada mereka (penduduk Yaman) bahwa Allah telah mewajibkan mereka untuk membayar zakat yang akan diambil dari orang kaya diantara mereka dan memberikannya kepada orang miskin diantara mereka. Dengan demikian pemerintah pusat berhak menerima keuntungan hanya bila terjadi surplus yang tidak dapat didistribusikan lagi kepada orang-orang yang berhak, dan ditambah kekayaan yang dikumpulkan di Madinah. 


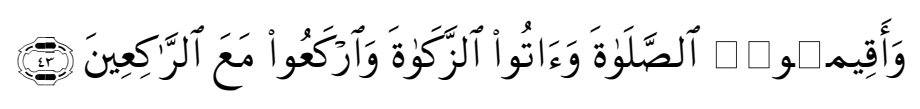

Artinya: Dan Dirikanlah shalat, tunaikanlah zakat dan ruku'lah beserta orangorang yang ruku'.(Q.S. Al Baqarah: 43).

Di Masa Rasulullah SAW, zakat dikenakan pada hal-hal berikut:

1). benda logam yang terbuat dari emas dan perak

2). binatang ternak unta, sapi, domba, kambing

3). Berbagai jenis barang dagang termasuk budak dan hewan

4). Hasil pertanian termasuk buah-buahan

5). Luqta, harta benda yang ditinggalkan musuh

6). Barang temuan

c. Ushr

Ushr adalah pajak yang dikumpulkan dari hasil perdagangan dan bisnis yang dilakukan oleh warga Negara di Negara Islam.

d. Fai

Fai adalah harta kekayaan yang diambil dari musuh tanpa melakukan peperangan. Harta ini harus diserahkan kepada Baitul mal.

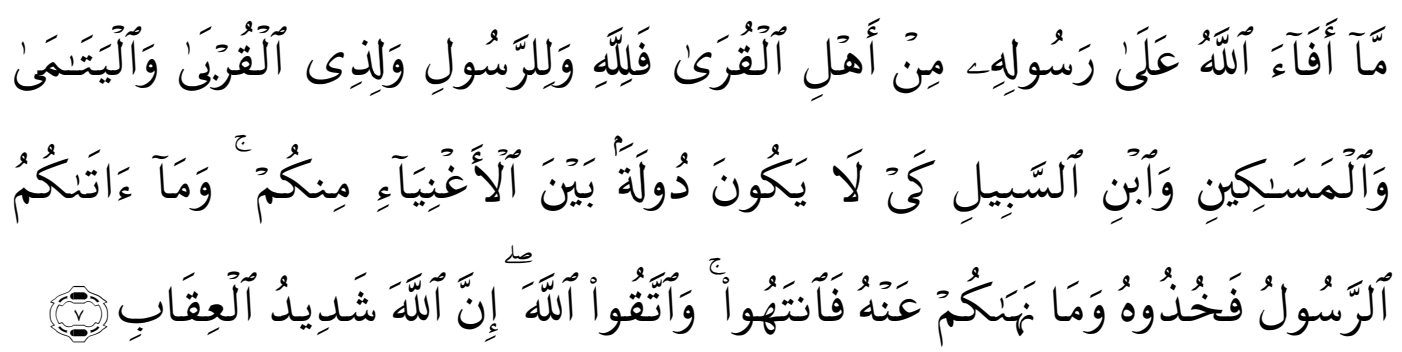

Artinya: Apa saja harta rampasan (fai-i) yang diberikan Allah kepada RasulNya (dari harta benda) yang berasal dari penduduk kota-kota Maka adalah untuk Allah, untuk rasul, kaum kerabat, anak-anak yatim, orang-orang miskin dan orang-orang yang dalam perjalanan, supaya harta itu jangan beredar di antara orang-orang Kaya saja di antara kamu. apa yang diberikan Rasul kepadamu, Maka terimalah. dan apa yang dilarangnya bagimu, Maka tinggalkanlah. dan bertakwalah kepada Allah. Sesungguhnya Allah amat keras hukumannya.(Q.S. Al-Hasyr: 7) 
e. Jizyah

Jizyah adalah pajak yang dibayar oleh orang nonmuslim khususnya ahli kitab, untuk jaminan perlindungan jiwa, property, ibadah, bebas dari nilai-nilai dan tidak wajib militer. Pada masa Rasulullah SAW, besarnya jizyah satu dinar per tahun untuk orang dewasa yang mampu membayarnya. Perempuan, anakanak, orang tua dibebaskan dari kewajiban jizyah. Diantara ahli kitab yang harus membayar jizyah sejauh yang diketahui adalah Nashara Najran.

\section{f. Kharaj}

Kharaj atau pajak tanah dipungut dari nonmuslim ketika khaibar ditaklukkan. Tanahnya diambil alih oleh orang muslim dan pemilik lamanya harus menawarkan untuk mengolah tanah tersebut sebagai pengganti sewa tanah dan bersedia memberikan sebagian hasil produksi kepada negara. Kharaj dibayar oleh orang-orang non-muslim seperti halnya dengan kaum muslimin membayar $u s h r$ dari hasil pertanian.

g. Uang tebusan untuk para tawanan perang (hanya pada kasus perang Badr)

h. Pinjaman-pinjaman untuk pembayaran uang pembebasan kaum muslimin

i. Khums atau rikaz

Khums atau proportional tax adalah persentasi tertentu dari rampasan perang yang diperoleh oleh tentara Islam sebagai ghanimah setelah peperangan, dan memperoleh kemenangan.(Masyhuri, 2007:87)

j. Amwal fadilah (berasal dari harta benda kaum muslimin yang meninggal tanpa ahli waris)

k. wakaf, harta benda yang didedikasikan oleh seseorang kepada kaum muslimin untuk kepentingan agama Allah dan pendapatannya akan didepositokan di Baitul Mal.

Rasulullah merupakan kepala Negara pertama yang memperkenalkan konsep baru di bidang keuangan Negara di abad ketujuh, yaitu semua hasil Nazharat, Vol. 26 No. 01, Juni 2020 
penghimpunan kekayaan Negara harus dikumpulkan terlebih dahulu dan kemudian dikeluarkan sesuai dengan kebutuhan Negara. tempat pusat pengumpulan dana itu disebut Baitul Mal yang di masa Nabi saw terletak di Masjid Nabawi.

Belanja pemerintah pada masa Rosulullah untuk hal-hal pokok yang meliputi: biaya pertahanan Negara, penyaluran zakat, untuk mereka yang berhak menerimanya, pembayaran gaji pegawai pemerintah, pembayaran utang Negara serta bantuan untuk musafir. Untuk mengelola dan sumber penerimaan Negara dan sumber pengeluaran Negara maka Rasulullah menyerahkannya kepada Baitul Mal dengan menganut asas anggaran berimbang balance budgetartinya semua penerimaan habis digunakan untuk pengeluaran Negara. Begitulah Rasulullah meletakan dasar-dasar kebijaksanaan fiskal yang berlandaskan keadilan, sejak masa pemerintahan islam.

Kebijakan fiskal pada masa Rasulullah ada empat langkah yang dilakukan Rasulullah, diantaranya : (Amalia, 2010:19)

1) Peningkatan pendapatan nasional dan tingkat dari partisipasi kerja.

Dalam rangka meningkatkan permintaan agregat masyarakat Muslim di Madinah, Rasulullah melakukan kebijakan mempersaudarakan kaum Muhajirin dan Anshar. Hal ini menyebabkan terjadinya distribusi pendapatan dari kaum Anshar ke Muhajirin yang berimplikasi pada peningkatan permintaan total di Madinah.

2) Kebijakan pajak

Penerapan kebijakan pajak yang dilakukan Rasulullah seperti Kharaj, khums, dan zakat menyebabkan teciptanya Kestabilan harga dan mengurangi inflasi. 
3) Anggaran pengaturan APBN yang dilakukan Rasululah cermat, efektif, dan efisien menyebabkan jarang terjadinya defisit anggaran meskipun sering terjadi peperangan.

4) Kebijakan fiskal khusus

Rasulullah menerapkan beberapa kebijakan fiskal secara khusus untuk pengeluaran Negara yaitu : menerima bantuan kaum muslmin secara sukarela untuk memenuhi kebutuhan pasukan muslim; meminjam peralatan dari kaum non muslim secara Cuma-Cuma dengan jaminan pengembalian dan ganti rugi bila terjadi kerusakan; meminjam uang dari orang-orang tertentu untuk diberikan kepada para muallaf, serta menerapkan kebijakan insentif untuk menjaga pengeluaran dan meningkatkan partisipasi kerja dan produksi kaum muslimin.

Pemerintahan suatu Negara dipandang sebagai satu-satunya penguasa kekayaan dan perbendaharaan Negara. Dengan demikian, pemerintah bebas mengambil harta kekayaan rakyatnya sebanyak mungkin serta membelanjakannya. Hal ini bearti, sebelum Islam datang, tidak ada konsep tentang keuangan public dan perbendaharaan Negara dunia.

Dalam Negara Islam, tampak kekuasaan dipandang sebagai sebuah amanah yang harus dilaksanakan sesuai dengan perintah Al-Qur'an. Hal ini dipraktekan oleh Rasulullah Saw. sebagai seorang kepala Negara secara baik dan benar.

Status harta hasil pengumpulan itu adalah milik Negara dan bukan milik individu.Tempat pengumpulan itu disebut sebagai Baitul Mal. Pada masa pemerintahan Rasulullah Saw. Baitul Mal ketika itu digunakan sebagai kantor pusat Negara yang sekaligus berfungsi sebagai tempat tinggal Rasulullah. 
Harta yang merupakan sumber pendapatan Negara di simpan di masjid dalam jangka waktu singkat untuk kemudian didistribusikan kepada masyarakat hingga tidak tersisa sedikit pun.

\section{Kebijakain Fiskal Masa Abu Bakar As-Shiddiq}

Pada masa pemerintahan Abu Bakar As-Shiddiq belum banyak perubahan dan inovasi baru yang berkaitan dengan sektor ekonomi dan keuangan negara. Kondisinya masih seperti pada masa Rasulullah Saw. Kondisi ini dibentuk oleh konsentrasi Abu Bakar untuk mempertahankan eksistensi Islam dan kaum Muslimin. Para sahabat masih terfokus untuk memerangi mereka yang enggan membayar zakat setelah wafatnya Rasulullah dan memerangi yang murtad dan gerakan nabi palsu.

Hasil pengumpulan zakat dijadikan sebagai pendapatan Negara dan disimpan dalam Baitul Mal untuk langsung didistribusikan seluruhnya kepada kaum muslimin hingga tidak ada yang tersisa. Seperti halnya Rasulullah Saw., Abu Bakar As-Shiddiq juga melaksanakan kebijakan pembagian tanah hasil taklukan yang lain tetap menjadi tanggungan Negara dalam mendistribusikan harta Baitul Mal tersebut, Abu Bakar menerapkan prinsip kesamarataan, yakni memberikan jumlah yang sama kepada semua sahabat Rasulullah Saw.(Hamzah, 2009:47)

Dengan demikian, selama masa pemerintahan Abu Bakar, harta Baitul Mal tidak pernah menumpuk dalam jangka waktu yang lama karena langsung didistribusikan kepada seluruh kaum muslimin. Sewaktu Abu Bakar ash-Shiddiq wafat pun, hanya ditemukan satu dirham dalam perbendaharaan Negara. Apabila pendapatan meningkat, seluruh kaum muslimin mendapat manfaat yang sama dan tidak ada seorang pun yang dibiarkan dalam kemiskinan. Kebijakan tersebut 
berimplikasi pada peningkatan aggregate demand dan aggregate supply yang pada akhirnya akan menaikkan total pendapatan nasional.(Amalia: 2010;33)

\section{Kebijakan Fiskal Masa Umar Ibn Al-Khattab}

Seiring dengan semakin meluasnya wilayah kekuasaan Islam pada masa pemerintahan Umar ibn al-khattab, pendapatan Negara mengalami peningkatan yang signifikan. Beliau membuat keputusan bahwa untuk tidak menghabiskan harta Baitul Mal sekaligus, tetapi dikeluarkan secara bertahap sesuai dengan kebutuhan yang ada., bahkan diantaranya disediakan dana cadangan. Dalam hal pendistribusian harta Baitul Mal, sekalipun berada dalam kendali dan tanggung jawabnya, para pejabat Baitul Mal yang berupa zakat dan ushr. Khalifah Umar ibn Al-Khattab juga membuat ketentuan bahwa pihak eksekutif tidak boleh ikut campur dalam mengelola harta Baitul Mal. Negara bertanggung jawab untuk menyediakan makanan bagi para janda, anak-anak yatim, serta anak-anak terlantar; membiayai penguburan orang-orang miskin;membayar utang orangorang yang bangkrut; membayar diyat untuk kasusu-kasusu tertentu.

Untuk mendistribusikan harta Baitul Mal, khalifah Umar mendirikan beberapa departemen yang dianggap perlu: (Karim, 2009:36)

a. Departemen Pelayanan Militer

b. Departemen Kehakiman dan Eksekutif

c. Departemen Pendidikan dan Pengembangan Islam

d. Departemen Jaminan Sosial

Pada masa pemerintahannya, Khalifah Umar mengklasifikasi pendapatan Negara menjadi empat bagian, yaitu: (Amalia, 2010:36)

1. Pendapatan zakat dan ' $u s h r$

2. Pendapatan khums dan sedekah

3. Pendapatan kharaj, fai, jizyah, 'ushr (pajak perdagangan) 
4. Pendapatan lain-lain

Diantara alokasi pengeluaran dari harta Baitul Mal tersebut, dana pensiun merupakan pengeluaran Negara yang paling penting. Prioritas berikutnya adalah dana pertahanan Negara dan dana pembangunan.

\section{Kebiajkan Fiskal Masa Pemerintahan Ustman ibn Affan}

Masa pemerintahannya berlangsung selama 12 tahun. Pada enam tahun pertama masa pemerintahannya, khalifah Ustman ibn Affan melakukan penataan baru dengan mengikuti kebijakan Umar ibn Khattab. Dalam rangka pengembangan sumber daya alam, beliau melakukan pembuatan saluran air, pembangunan jalan-jalan, dan pembentukan organisasi kepolisian secra permanent untuk mengamankan jalur perdagangan. Dalam pendistribusian harta Baitul Mal, khalifah Ustman ibn Affan menerapkan prinsip keutamaan seperti halnya Umar ibn Khattab. Khalifah Ustman ibn Affan tetap mempertahankan system pemberian bantuan dan santunan serta memberikan sejumlah besar uang kepada masyarakat yang berbeda-beda. Dalam hal penegelolaan zakat, khlaifah Ustman ibn Affan mendelegasikan kewenangan menaksir harta yang dizakati kepada para pemiliknya. Hal ini dilakukan untuk mengamankan zakat dari berbagai gangguan dan masalah dalam pemeriksaan kekayaan yang tidak jelas oleh beberapa oknum pengumpul zakat.

Oleh karena itu, khalifah Ustman ibn Affan membuat beberapa perubahan administrasi tingkat atas dan pergantian beberapa gubernur.

\section{Kebijakan Masa Pemerintahan Ali Bin Abi Thalib}

Ali bin Abi Thalib membenahi sistem administrasi Baitul Mal, baik di tingkat pusat maupun daerah hingga semuanya berjalan dengan baik. Dalam pendistribusian harta Baitul Mal, khalifah Ali ibn Abi halib menerapkan sistem pemerataan. Selama masa pemerintahannya, khalifah Ali ibn Ali Thalib 
menetapkn pajak terhadap pemilik hutan sebesar 4000 dirham dan mengizinkan Ibnu Abbas, Gubernur Kufah, memungut zakat terhadap sayuran segar yang akan digunakan sebagai distribusi setiap pekan sekali untuk pertama kalinya diadopsi. Hari kamis adalah hari pendistribusian. Pada hari itu, semua perhitungan diselesaikan dan pada hari sabtu dimulai perhitungan baru. Selain itu langkah penting yang dilakukan khalifah Ali ibn Abi Thalib pada masa pemerintahannya adalah percetakan mata uang koin atas nama Negara Islam. Hal ini menunjukkan bahwa pada masa pemerintahan tersebut, kaum muslimin telah menguasai teknologi peleburan besi dan percetakan koin. Namun demikian, uang yang dicetak oleh kaum muslimin itu tidak dapat beredar dengan luas karena pemerintahan Ali ibn Abi Thalib berjalan sangat singkat seiring dengan terbunuhnya sang Khalifah pada tahun keenam pemerintahannya. (Karim, 2010:78)

Dari segi alokasi pengeluaran kurang lebih masih tetap sama sebagaimana halnya pada masa pemerintahan khalifah Umar. Khalifah Ali memiliki konsep yang jelas tentang pemerintahan, administrasi umum dan masalah-masalah yang berkaitan dengannya. Konsep ini dijelaskan dalam suratnya yang terkenal yang ditujukan kepada Malik Ashter bin Harits. Surat yang mendeskripsikan tugas, kewajiban serta tanggung jawab para penguasa dalam mengatur berbagai prioritas pelaksanaan dispensasi keadilan serta pengawasan terhadap para pejabat tinggi dan staf-stafnya.

\section{Kabijakan Fiskal Zaman Sekarang}

Kebijakan fiskal merujuk pada kebijakan yang dibuat pemerintah untuk mengarahkan ekonomi suatu negara melalui pengeluaran dan pendapatan (berupa pajak) pemerintah. Kebijakan fiskal berbeda dengan kebijakan moneter, yang bertujuan menstabilkan perekonomian dengan cara mengontrol tingkat 
bunga dan jumlah uang yang beredar. Instrumen utama kebijakan fiskal adalah pengeluaran dan pajak.

Selama ini kita mengenal tiga sistem perekonomian yang berlaku di dunia yaitu system Islam, sistem kapitalis dan sistem sosialis. (Desiana, 2011:129-139) Namun untuk di Indonesia terdapat system ekonomi campuran, dimana sistem campuran adalah sebuah sistem perekonomian dengan adanya peran pemerintah yang ikut serta menentukan cara-cara mengatasi masalah ekonomi yang dihadapi masyarakat. Tetapi campur tangan ini tidak sampai menghapuskan sama sekali kegiatan-kegiatan ekonomi yang dilakukan pihak swasta yang diatur menurut prinsip-prinsip cara penentuan kegiatan ekonomi yang terdapat dalam perekonomian pasar.

Bentuk-bentuk campur tangan pemerintah antara lain :

1. Membuat peraturan-peraturan, dengan maksud untuk menghindari praktek tidak sehat dalam perekonomian pasar.

2. Secara langsung ikut serta dalam kegiatan-kegiatan ekonomi. Ikut serta pemerintah dilakukan dengan mendirikan perusahaan-perusahaan yang menyediakan barang atau jasa-jasa dalam kehidupan masyarakat. Contoh: Perusahaan Air Minum.

Kebijakan fiskal yang dilakukan pemerintah merupakan kebijakan didalam bidang perpajakan (penerimaan) dan pengeluarannya, Kedua kebijakan ini merupakan wahana utama bagi peran aktif pemerintah dibidang ekonomi. (Desiana, 2011:129-139) Pada dasarnya sebagian besar upaya stabilisasi makro ekonomi berfokus pada pengendalian atau pemotongan anggaran belanja pemerintah dalam rangka mencapai keseimbangan neraca anggaran. Oleh karena itu, setiap upaya mobilisasi sumber daya untuk membiayai pembangunan publik yang penting hendaknya tidak hanya difokuskan pada sisi pengeluaran saja, tetapi juga pada sisi penerimaan pemerintah. Pinjaman dalam dan luar negeri 
dapat digunakan untuk menutupi kesenjangan tabungan. Dalam jangka panjang, salah satu potensi pendapatan yang tersedia bagi pemerintahan untuk membiayai segala usaha pembangunan adalah penggalakan pajak. Selain itu, sebagai akibat ketiadaan pasar-pasar uang domestik yang terorganisir dan terkontrol dengan baik, sebagian besar pemerintahan Negara- Negara Dunia Ketiga memang harus mengandalkan langkah-langkah fiskal dalam rangka mengupayakan stabilisasi perekonomian nasional dan memobilisasikan sumber-sumber daya ( keuangan) domestic.

Dari berbagai sistem ekonomi yang ada, dengan segala kelebihan dan kekurangan yang dimiliki, sistem ekonomi Islam dianggap sebagai smart solution dari berbagai sistem ekonomi yang ada karena secara etimologi maupun secara empiris, terbukti sistem ekonomi Islam menjadi sistem ekonomi yang mampu memberikan kemakmuran dan kesejahteraan. (Desiana, 2011:162)

Beberapa pandangan kebijakan fiskal menurut pandangan ahli ; Kebijakan Fiskal adalah langkah-langkah pemerintah untuk membuat perubahanperubahan dalam sistem pajak atau dalam perbelanjaannya dengan maksud untuk mengatasi masalah-masalah ekonomi yang dihadapi.(Sukirno, 2003;23)

Kebijakan Fiskal adalah kebijakan ekonomi yang digunakan pemerintah untuk mengelolah/ mengarahkan perekonomian ke kondisi yang lebih baik atau yang diinginkan dengan cara mengubah- ubah penerimaan dan pengeluaran pemerintah. Sedangkan dalam ekonomi islam, kebijakan fiskal merupakan salah satu perangkat untuk mencapai tujuan syariah yang di jelaskan oleh Imam AlGhazali, termasuk meningkatkan kesejahteraan dengan tetap menjaga keimanan, kehidupan, intelektualitas, kekayaan, dan kepemilikan. Jadi, bukan hanya untuk mencapai keberlangsungan (pembagian) ekonomi untuk masyarakat yang paling besar jumlahnya, tapi juga membantu meningkatkan spiritual dan menyebarkan pesan dan ajaran islam seluas mungkin. 
kebijakan memiliki dua prioritas, yang pertama adalah mengatasi defisit anggaran pendapatan dan belanja Negara (APBN) dan masalah-masalah APBN lainnya. Defisit APBN terjadi apabila penerimaan pemerintah lebih kecil dari pengeluarannya. Dan yang kedua adalah mengatasi stabilitas ekonomi makro, yang terkait dengan antara lain ; pertumbuhan ekonomi, tingkat inflasi, kesempatan kerja dan neraca pembayaran.

Sedangkaan, kebijakan fiskal terdiri dari perubahan pengeluaran pemerintah atau perpajakkan dengan tujuan untuk mempengaruhi besar serta susunan permintaan agregat. (Septyan, 2014) Indicator yang biasa dipakai adalah budget defisit yakni selisih antara pengeluaran pemerintah (dan juga pembayaran transfer) dengan penerimaan terutama dari pajak.

Kebijakan fiskal merujuk pada kebijakan yang dibuat pemerintah untuk mengarahkan ekonomi suatu negara melalui pengeluaran dan pendapatan (berupa pajak) pemerintah.

Berdasarkan dari beberapa teori dan pendapat yang dijelaskan diatas dapat disimpulkan bahwa kebijakan fiskal adalah suatu kebijakan ekonomi yang dilakukan oleh pemerintah dalam pengelolaan keuangan negara untuk mengarahkan kondisi perekonomian menjadi lebih baik yang terbatas pada sumber-sumber penerimaan dan alokasi pengeluaran negara yang tercantum dalam APBN.

Tujuan kebijakan fiskal dalam ekonomi Islam berbeda dari ekonomi konvensional, namun ada kesamaan yaitu dari segi sama-sama menganalisis dan membuat kebijakan ekonomi. Tujuan dari semua aktivitas ekonomi bagi semua manusia adalah untuk memaksimumkan kesejahteraan hidup manusia, dan kebijakan publik adalah suatu alat untuk mencapai tujuan tersebut. (Desiana, 2011:214) 
Pada sistem konvensional, konsep kesejahteraan hidup adalah untuk mendapatkan keuntungan maksimum bagi individu di dunia ini. Namun dalam Islam, konsep kesejahteraannya sangat luas, meliputi kehidupan di dunia dan di akhirat serta peningkatan spiritual lebih ditekankan daripada pemilikan material. Jadi tujuan kebijakan fiskal dalam ekonomi islam adalah untuk menganalisis dan membuat kebijakan ekonomi untuk memaksimumkan kesejahteraan hidup manusia mencakup baik di dunia dan akhirat. Ada beberapa hal penting dalam ekonomi islam yang berimplikasi bagi penentuan kebijakan fiskal adalah sebagai berikut:

a) Mengabaikan keadaan ekonomi dalam ekonomi islam, pemerintah muslim harus menjamin bahwa zakat dikumpulkan dari orang-orang muslim yang memiliki harta melebihi nisab dan yang digunakan untuk maksud yang dikhususkan dalam kitab suci Al-Qur'an.

b) Tingkat bunga tidak berperan dalam system ekonomi islam.

c) Ketika semua pinjaman dalam islam adalah bebas bunga, pengeluaran pemerintah akan dibiayai dari pengumpulan pajak atau dari bagi hasil.

d) Ekonomi islam diupayakan untuk membantu ekonomi masyarakat muslim terbelakang dan menyebarkan pesan-pesan ajaran islam.

e) Negara Islam adalah Negara yang sejahtera, kesejahteraan meliputi aspek material dan spiritual.

f) Pada saat perang, islam berharap orang-orang itu memberikan tidak hanya kehidupannya, tapi juga hartanya untuk menjaga agama.

g) Hak perpajakan dalam islam tidak tak terbatas.

Kebijaksanaan fiskal memegang peranan kunci dalam mempertahankan stabilitas ekonomi menghadapi kekuatan-kekuatan internal dan eksternal. Dalam rangka mengurangi dampak internasional fluktuasi siklis pada masa boom, harus diterapkan pajak ekspor dan impor. Pajak ekspor dapat menyedot rejeki nomplok 
yang timbul dari kenaikkan harga pasar. Sedangkan bea impor yang tinggi pada impor barang konsumsi dan barang mewah juga perlu untuk menghambat penggunaan daya beli tambahan.

Kebijakan fiskal bertujuan untuk menanggulangi inflasi salah satunya adalah dengan cara penetapan pajak langsung progresif yang dilengkapi dengan pajak komoditi, karena pajak seperti ini cendrung menyedot sebagian besar tambahan pendapatan uang yang tercipta dalam proses inflasi. (Website: Cara mengatasi Inflasi)

Untuk meningkatkan dan mendistribusikan pendapatan nasional Kebijakan fiskal yang bertujuan untuk mendistribusikan pendapatan nasional terdiri dari upaya meningkatkan pendapatan nyata masyarakat dan mengurangi tingkat pendapatan yang lebih tinggi, upaya ini dapat tercipta apabila adanya investasi dari pemerintah seperti pelancaran program pembangunan regional yang berimbang pada berbagai sektor perekonomian. Kebijakan fiskal mempunyai beberapa fungsi, diantaranya:

a). Fungsi Alokasi, yaitu untuk mengalokasikan faktor-faktor produksi yang tersedia dalam masyarakat sedemikian rupa sehingga kebutuhan masyarakat berupa Public goods seperti jalan, jembatan, pendidikan dan tempat ibadah dapat terpenuhi secara layak dan dapat dinikmati oleh seluruhn masyarakat.

b). Fungsi Distribusi, yaitu fungsi yang mempunyai tujuan agar pembagian pendapatan nasional dapat lebih merata untuk semua kalangan dan tingkat kehidupan.

c). Fungsi Stabilisasi, agar terpeliharanya keseimbangan ekonomi terutama berupa kesempatan kerja yang tinggi, tingkat harga-harga umum yang relatif stabil dan tingkat pertumbuhan ekonomi yang memadai.(Sari:2014)

Kebijakan fiskal merupakan kebijakan yang yang merujuk pada kebijakan pemerintah melalui pengeluaran dan pendapatan.kebijakan fiskal 
berbeda dengan kebijakan moneter,instrument utama kebijakan fiskal adalah menstabilkan pengeluaran dan pendapatan ekonomi suatu Negara. Kebijakan fiskal mempunyai tujuan terhadap sistem ekonomi baik ekonomi islam ataupun ekonomi kapitalis kebijaka fiskal mempunyai tujuan yang amat sangat berbeda begitu pula definisinya.namun definisi dan tujuan kebijakan fiskal dari sistem ekonomi islam lebih luas definisi dan tujuanya dibandingkan dengan ekonomi kapitalis yang hanya mengutamaka aspek material saja tanpa menyangkut aspeik spiritualnya. Sangat berbeda dengan ekonomi Islam yang menyangkut semua aspek kehidupan dari mulai sebelum kita lahir sampai kehidupan kita setelah kita hidup semua dibshas dalam sistem ekonomi Islam. Selain tujuan kebijakan fiskal juga mempunyai fungsi dan bentuk-bentuk dalam sistem ekonomi. Fungsi tersebut meliputi fungsi alokasi, distribusi dan stabilisasi. Kebijakan fiskal dalam Islam tidak lepas dari tujuan luhur syariat Islam, yaitu : memelihara keturunan, akal, kemuliaan, jiwa, harta, agama, ketentraman/keamanan dan memelihara Negara. (Desiana, 2011:214)

\section{DAFTAR PUSTAKA}

Departemen Agama RI, Al-Qur`an dan Terjemahnya, Bandung: Diponegoro, 2008

Adiwarman A. Karim, Ekonomi Makro Islami edisi kedua, Jakarta:PT Rajagrafindo Persada, 2010

Ahmad Yani,., Hubungan Keuangan Antara Pemerintah Pusat Dan Daerah Di Indonesia, Divisi Buku Perguruan Tinggi, Jakarta: Raja Grafindo Persada, 2004

Ali Hamzah, Khazanah Fiqih Islam, Kerinci: STAIN Kerinci, 2009

Ali Hasan, Masail Fiqiyah, Jakarta: Rajawali Press, 2003

A. Hasjmy, Sejarah Kebudayaan Islam, Jakarta: Bulan Bintang, 1975

Choudhury, Money in Islam: a Study in Islamic Political Economy, London: The Macmillan Press Ltd,

Dian Puji N. Simatupang, Determinasi Kebijaksanaan Anggaran Negara Indonesia, Studi Yuridis, Jakarta: Papas Sinar Sinanti, 2005

Desiana, 2001, Ekonomi Islam Dalam Menjawab Tantangan Global, Kerinci: STAIN Kerinci,

Ewis Amalia, Sejarah Pemikiran Ekonomi Islam dari Masa Klasik Hingga Kontemporer, Jakarta: Granada Press, 2010 
Mike Oktaviana,Samsul Bahry Harahap: Kebijakan Fiskal Zaman Rasulullah Dan Khulafarasyidin

Ghazali, Abu Hamid Muhammad Al, Ihya Ulum al-Din, Beirut: Dar al-Nadwah, tt Gita Danupranata, Ekonomi Islam, Jakarta: Saung Media Utama, 2006

Heri Sudarsono, Konsep Ekonomi Islam Suatu Pengantar Yogyakarta:Ekonesia, 2004

Hasan Ibrahim Hasan, Sejarah Kebudayaan Islam Jilid 2, Jakarta: Kalam Mulia, 2003

Ira M. lapidus, Sejarah Sisial Umat Islam, Jakarta: Raja Grafindo Persada, 1999

Imam Al-Ghazali, Ringkasan Ihya Ulumuddin, Surabaya: GitaMedia Press, 2003

Johan Arifin, Etika Bisnis Islami, Semarang: Wali Songo Press, 2009

Masyhuri, Teori Ekonomi Dalam Islam. Jakarta: LKPM. 2007

M. nur Rianto Al Arif, Teori Makro ekonomi Islam Konsep, Teori, dan Analisis, Bandung:Alfabeta, 2010

M. Suparmoko, Keuangan Negara dalam Teori dan Praktik Yogyakarta: BPF Yogyakarta, 1997

Muchdarsah Sinaungan, Uang dan Bank, Jakarta: Rineka Cipta, 1996

Samuelson dan William D. Nordhaus, Makroekonomi: Edisi Keempatbelas, terj. Haris Munandar Jakarta; Penerbit Erlangga, 1997

Suharsimi Arikunto, Prosedur Penelitian Kualitatif, cet. XIII, Bandung: Remaja Rosda Karya, 2000

Sadono Sukirno, 2003, Pengantar Teori Makro Ekonomi, Jakarata: Raja Grafindo,

Sugianto, 2004, Pajak dan Retribusi Daerah, Jakarta: Grasindo

Taqiyuddin an-Nabhani, Membangun Sistem Ekonomi Alternatif Perspektif Islam Surabaya: Risalah Gusti, 1996

Septyan, Kebijakan Fiskal, Online senin 3 februari 2014 http:/ / septyanpemburu.blogspot.com/2013/01/pelaksana-organisasi-bisnis.html

Syayid Sabiq, Fikih Sunnah Jilid 2, Jakarta: Cakrawala, 2008

Berita terhangat, cara mengatasi Inflasi, http:/ / www.beritaterhangat/2012/08/cara-mengatasi-inflasi. html

Heni Afriliana Sari, Kebijkan Fiskal, online Senin 3 Februari 2014 http:/ I henisari.com/2011/03/kebijakan-fiskal-kebijakan-fiskal.html

Merza Gamal, Uang Perspektif Islam, http://www.halalguide.info, 19 september 2013 